ISSN 2413-0877 Volume 2 (2015) 180

The 3rd International Conference on Biological Science 2013

(The 3rd ICBS-2013)

\title{
EFFECTS OF CHROMIUM (Cr) ON FRESHWATER MUSSEL Anodonta woodiana (Lea, 1834): DISTRIBUTION, BIOACCUMULATION, AND GENOMIC DNA DAMAGE
}

\author{
Andhika Puspito Nugroho ${ }^{1,3}$, Niken Satuti Nur Handayani², \\ I Gede Angga Pramudita ${ }^{3}$ \\ ${ }^{1}$ Laboratory of Ecology and Conservation, Faculty of Biology, \\ Universitas Gadjah Mada, Indonesia \\ ${ }^{2}$ Laboratory of Genetics, Faculty of Biology, Universitas Gadjah Mada, Indonesia \\ ${ }^{3}$ Student of Faculty of Biology, Universitas Gadjah Mada, Indonesia \\ e-mail: anggapramudita09@gmail.com
}

\begin{abstract}
Chromium $(\mathrm{Cr})$ is one of metals which are toxic to organisms at elevated concentration. In freshwater ecosystems, Cr concentration can be increased due to discharge of chromium-containing wastewater coming from leather tanning and electroplating industries. Mussels are known to accumulate metals in their body. The objectives of this research were to study distribution and bioaccumulation of $\mathrm{Cr}$ in the freshwater mussel Anodonta woodiana, and its effect on genomic DNA. In this research, mussels were exposed to Cr via water (25 ig $\left.\mathrm{L}^{-1}\right)$ for 24 days, followed by 12 days of depuration. On days $0,1,6,12,24$ (exposure), and day 30 and 36 (depuration), 3 mussels were sampled and dissected into gills, mantle, digestive gland, intestines, foot, kidney, and adductors. Hemolymph (HML) and extra pallial fluids (EPF) were withdrawn from the posterior adductor. Bioaccumulation of $\mathrm{Cr}$ in all organs, $\mathrm{HML}$, and EPF was determined by using Atomic Absorbance Spectrophotometer (AAS). Analysis of genome DNA damage in the gills was qualitatively determined by using gel agarose electrophoresis. The results showed that chromium concentrations increased in all organs within 24 days of exposure, the highest levels being in the gills and mantle. $\mathrm{Cr}$ concentrations were decreased within 12 days of depuration. For HML and EPF, Cr concentrations were decreased during exposure, back to normal at the end of depuration. During exposure, Cr induced the damage of genome DNA in the gills, and back to normal at day 12 of depuration.
\end{abstract}

Keywords: chromium (Cr); Anodonta woodiana; bioaccumulation; DNA damage.

ISSN 2413-0877 @ 2015 The Authors.

Published by KnowledgeE Publishing Services This is an open access article under the CC BY-NC-ND license (http://creativecommons.org/licenses/by-nc-nd/4.0)

Selection and Peer-review under responsibility of the 3rd ICBS-2013

Doi http://dx.doi.org/10.18502/kls.v2i1.139 